\title{
Article
}

\section{Christmas quiz!}

Davies, Janice Anne

Available at http://clok.uclan.ac.uk/36135/

Davies, Janice Anne (2020) Christmas quiz! Journal of Prescribing Practice, 2 (12). p. 666. ISSN 2631-8385

It is advisable to refer to the publisher's version if you intend to cite from the work.

10.12968/jprp.2020.2.12.666

For more information about UCLan's research in this area go to

http://www.uclan.ac.uk/researchgroups/ and search for < name of research Group>.

For information about Research generally at UCLan please go to http://www.uclan.ac.uk/research/

All outputs in CLoK are protected by Intellectual Property Rights law, including Copyright law. Copyright, IPR and Moral Rights for the works on this site are retained by the individual authors and/or other copyright owners. Terms and conditions for use of this material are defined in the policies page.

\section{CLoK}

Central Lancashire online Knowledge www.clok.uclan.ac.uk

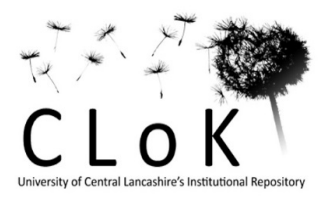


JPrP December 2020

\section{CHRISTMAS NUMBERS QUIZ}

Enter your answers into the grid to reveal a Christmas word!

How many gifts in total were given in the 'Twelve Days of Christmas' song?

How many gold rings are in the above song?

What is the missing number in the movie 'Miracle on xx street'?

How many of the reindeer's names begin with D?

How many days after Christmas should you take your tree down?

What is the value of the penny that was traditionally hidden in a Christmas pudding?

How many ghosts show up in 'a Christmas carol'?

How many reindeer are there?

What is the number of letters in the nation's favourite Christmas bird?

Insert a grid showing these words with the red letters in a vertical line

THREE HUNDRED AND SIXTY FOUR

FIVE

C

THIRTY FOUR

THREE

A

TWELVE

SIX

FOUR

SEVEN

SIX 